\title{
Erken Düşünme Becerilerine Yönelik Türkiye'de Yapılan Bilimsel Çalışmaların İncelenmesi
}

\section{Investigation of Scientific Studies Performed in Turkey on Early Thinking Skills}

\author{
Şule BILLGiçiD1, Prof. Dr. Adalet KANDIR iD2
}

\begin{abstract}
Öz
Bilimsel araştırmaların ön plana çıktığı 21.yüzyıl toplumları için problem çözme, eleştirel düşünme, yaratıcı düşünme ve etkili karar verme becerilerine sahip bireylerin varlığı önem kazanmaktadır. Evrensel değerler haline gelen bu yeterlilikler düşünme becerilerinin önemini vurgulamaktadır. Düşünme becerileri için erken dönemler kritik öneme sahiptir. Araştırma erken düșünme becerilerine yönelik Türkiye'de yapılan bilimsel çalışmaların incelenmesi amacıyla yapılmıştır. Araştırma verilerinin toplanmasında nitel araştırma yöntemlerinden doküman incelemesi kullanılmıştır. Doküman incelemesi için ilgili bilimsel alan yazınına Ulusal Tez Merkezi ve Google Akademik veri tabanlarından ulaşılmıştır. Erken düşünme becerilerine ve erken düşünme becerileriyle doğrudan ilișkili olan problem çözme becerisi, yaratıcı düşünme becerisi, eleştirel düşünme becerisi ve karar verme becerisine yönelik Türkiye'de yapılan 2002 yılı ve sonrası makaleler, yüksek lisans tezleri ve doktora tez çalışmaları doküman olarak kabul edilmiştir. Dokümanlar analiz edildiğinde problem çözme becerileriyle ilişkili çalışmaların diğer alt becerilerden daha fazla sayıda olduğu tespit edilmiştir. Problem çözme becerilerinde 'sosyal problem çözme' boyutunun üzerinde durulduğu görülmüştür. Yaratıcı düşünme becerileri çalışmalarında farklı yaklaşımlar, etkinlikler, aile, çevre etkenlerine yer verilmiştir. Eleştirel düşünme ve karar verme becerileri konusunda çocuklarla yapılan herhangi bir çalışmaya ulaşılmamıştır. Tez çalışmalarının büyük bölümünün 2010 yılı ve sonrasına ait olduğu görülmüştür.
\end{abstract}

Anahtar Kelimeler: Düşünme becerisi, problem çözme, yaratıcı düşünme, eleştirel düşünme, karar verme

Makale Türü: Derleme

\begin{abstract}
For the 21. century societies where scientific researches is at the forefront, the existence of individuals with problem solving, critical thinking, creative thinking and effective decision-making skills gains importance. These qualifications which have become universal values; express the importance of thinking skills. Early periods are critical for development of thinking skills. The purpose of this research is to examine scientific studies on early thinking skills in Turkey. Research data was collected by document review. Data/research for document analysis has been obtained from the National Thesis Center and Google Scholar databases. The documents in this research are related to early thinking skills and associated with early thinking skills such as problem-solving skills, creative thinking skills, critical thinking skills and decision-making skills. Documents; consisted of articles master's theses and doctoral dissertations conducted in Turkey in 2002 and later. When the documents are analyzed, studies on problem solving skills were detected to be more numerous than other sub-skills. It was found that the problem-solving skills was mostly focused on "social problem solving" dimension. Different approaches, activities, family and environmental factors are included in creative thinking skills studies. Any studies regarding critical thinking and decision-making skills studied with children. It was seen that most of the thesis dissertation conducted in 2010 or later.
\end{abstract}

${ }^{1}$ Gazi Üniversitesi, Gazi Eğitim Fakültesi, su-le91@ @ hotmail.com.
${ }^{2}$ Gazi Üniversitesi, Gazi Eğitim Fakültesi, akandir@gmail.com.

Atıf için (to cite): Bilgiç, Ş. ve Kandır, A. (2019). Erken düşünme becerilerine yönelik Türkiye'de yapılan bilimsel çalışmaların incelenmesi. Afyon Kocatepe Üniversitesi Sosyal Bilimler Dergisi, 22(1), 69-84. 
Keywords: Thinking skill, problem solving, creative thinking, critical thinking, decision making

Paper Type: Review

\section{Giriș}

Toplumların şekillenmesinde ve gelişmesinde toplumu oluşturan bireyler etkilidir. Dijital teknolojilerin ve bilimsel çalışmaların ön plana çıktığı 21 .yüzyıl toplumları için problem çözen, yaratıcı çözümler üreten, eleştirel ve bütünsel bakış açısına sahip bireylerin varlığı önem kazanmaktadır. Evrensel değerler haline gelen bu yeterlilikler zihinsel bir süreç olan ve desteklenip geliştirilmesi son derece önemli olan 'düşünme' olgusu ile ilişkilidir (Beyer, 1987, s. 27).

Değişen yaşam koşullarına bağlı olarak yaşadığımız çağda bilgiyi; pasif olarak alan, edilgen bireyler ile düşünen, sorgulayan, anlamlandıran ve ilişkilendiren bireyler arasındaki mesafenin gittikçe arttığı görülmektedir. Yapılan yeni araştırmalar yaşama uyum konusunda ön koşul sayılan becerilerden olan düşünsel eylemlerin önemsenme gerekçelerinden birisinin insanların bu becerilerden yoksun olması durumu olduğunu ortaya çıkarmıştır (Karsantık, 2016, s. 179). Oysaki başarılı toplumların düşünceye, düşünmeye yönelik becerilere ve bu becerilerin desteklenmesine verdiği önem ile eğitim politikalarına yön verdiği bilinmektedir.

Amaçlı ve bilinçli biçimde yapılan bilgiyi anlamlandırma ve anlama çabası olan'düşünme' eyleminin, zihindeki şemaları kullanmakta etkililiği sağlayan, farklı çözümlere odaklı ve bireylere özstrateji yolları yaratan beceriler olarak tanımlanan düşünce becerilerinden oluşan karmaşık ve sistematik bilişsel bir süreç olduğu görülmektedir (Emer, 2007, s. 18; Nickerson, 1988, s. 120; Trochim, 2001).

Kapsam ve yeterlilikler bakımından yaşam boyu kullanılan bilişsel, sosyal ve duygusal birçok beceriyle ilişskili olan düşünme becerilerinin; derin, mantıksal ve matabiliş düşünme, bilimsel ve teknolojik okur yazarlığın yanı sıra özgüven, özsaygı, empati gibi psikososyal becerileri desteklediği belirlenmiştir. Ayrıca Başarılı Zeka Kuramının temel becerilerinden uygulamalı düşünmenin çevreye uyum sağlama gibi önemli bir psikososyal beceriyi kapsadığ bilinmektedir (Jones, 2008, s. 21; Sternberg ve Grogorenko, 2004, s. 48; Tok, 2008, s. 109).

Bilişsel birçok beceri gibi düşünme becerileri için de erken dönemler kritik öneme sahiptir. Çocuklara erken yıllarda verilen düşünme eğitiminin; sorgulama, muhakeme etme, eleştirme, karşılaştıkları problemlere özgün ve etkili çözüm yolları bulma, karar verme stratejisi kazanma gibi birçok becerinin gelişiminde destekleyici rolü olduğu bilinmektedir. Ayrıca beyin gelişiminin ve beyindeki sinaptik bağların yoğun olarak şekillendiği yaşamın diğer gelişim dönemlerine temel oluşturacak erken çocukluk döneminde düşünme becerileri ve ilişkili diğer beceriler olan eleştirel düşünme becerisi, yaratıcı düşünme becerisi, problem çözme becerisi, karar verme becerisinin desteklenmesi son derece önemlidir.

İlgili literatür incelendiğinde düşünme becerilerinin öğretmen, öğrenci-çocuk ve aile üzerinde önemli etkilerini saptayan çalışmalarla birlikte çocuklara yönelik çalışma sayısının oldukça az olduğu görülmektedir. Çocuklarla ilgili sınırlı sayıda olan çalışmalarda düşünme becerilerinin, erken çocukluk döneminden itibaren kazandırılmasının gerekliliğine, düşünmenin ve düşünme becerilerinin öğretimine ve uygulanabilirliğine vurgu yapılmaktadır (Akbaba ve Kaya, 2015, s. 149; Kalkan Ay, 2014, s. 4). Bu bağlamda; erken çocukluk dönemi düşünme becerileri programlarına temel teşkil edecek, çocukların düşünme becerileri yönünden incelenmesi konusunda bilgi sunacak ve erken düşünme becerilerinin gelişimine öncülük edecek bütünsel bir anlayışla hazırlanmış, kapsamlı çalışmalara gereksinim duyulmaktadır. Araştırma ilgili alan yazında bu yöndeki boşluğu doldurması; orijinal, bilimsel bir çalışma olarak literatüre 
katkı sağlaması ve gelecekte yapılacak araştırmalara, okul öncesi program geliştirme çalışmalarına 1şık tutması açısından önemlidir.

Erken düşünme becerilerine yönelik Türkiye'de yapılan bilimsel çalışmaların incelenmesini amaçlayan bu araştırmanın; erken düşünme becerilerine iliş̧in yurt içindeki genel eğilim ile konunun derinliğini hakkında bilgi vermesi, bu alanda çalışma yapacak uzmanlara bakış açısı kazandırması ve literatüre katkı sağlaması beklenmektedir.

\section{Yöntem}

Erken düşünme becerilerine yönelik Türkiye'de yapılan ve Türkçe yayınlanan bilimsel çalışmaların incelenmesini amaçlayan bu araştırma betimsel niteliktedir. Araştırma verilerinin toplanmasında nitel araştırma yöntemlerinden doküman incelenmesi kullanılmıştır. Nitel model, üzerinde çalışlan konuyu derinlemesine incelemeyi amaçlayan bir yöntemdir (Karataş, 2015, s. 68). Doküman incelemesi, araştırılması amaçlanan olgu ya da olgular hakkında bilgi içeren yazılı materyallerin analizini kapsar (Yıldırım ve Şimşek, 2011, s. 191).

Araştırmada, Türkiye'de yapılan, Türkçe yayınlanan 2002-2017 yıllarını kapsayan ve Ocak-Şubat 2018 tarihlerinde ulaşılan erken düşünme becerilerine yönelik bilimsel çalışmalardan doktora yüksek lisans tezleri ve makaleler doküman olarak kabul edilmiştir.

Doktora- yüksek lisans tezlerine ve makalelere Yüksek Öğretim Kurulu Başkanlığı (YÖK) Tez Arşivi ve Google Akademik veri tabanlarından çalışmanın amacıyla ilişki olduğu belirlenen düşünme becerileri ve alt boyutlarına ilişkin "düşünme becerisi, problem çözme, yaratıcı düşünme, eleştirel düşünme, karar verme" anahtar sözcükleri ile tarama yapılarak ulaşılmıştır.

Araştırmada erken düşünme becerilerine yönelik Türkiye'de yapılan bilimsel çalışmalar kapsamında on doktora tezi, on iki yüksek lisans tezi, yedi makale incelenmiştir. Veri tabanlarından "düşünme becerisi" anahtar sözcügü ile yapılan taramada bir yüksek lisans tezi ve bir makale tespit edilmiştir. "Problem çözme " anahtar sözcüğü ile yapılan taramada on yedi tez çalışması, iki makale bulunmuştur. Tez çalışmalarının sekizi doktora tezi, dokuzu yüksek lisans tezidir."Yaratıcı düşünme " anahtar sözcüğü ile yapılan taramada üç tez çalışması, dört makale bulunmuştur. Tez çalışmalarının bir tanesi doktora iki tanesi yüksek lisans tezidir. "Karar verme" anahtar sözcüğü ile yapılan taramada bir yüksek lisans tezi bulunmuştur. Yüksek lisans tezleri kapsamında yer alan karar verme becerisine ilişkin Çok Amaçlı Karar Verme Konusunda Yeni Yaklaşımlar ve Okul Öncesi Eğitime İlişkin Bir Uygulama konulu tez taramada görülmekle birlikte tezin kendisine ve erken karar verme becerisine yönelik verilerine ulaşılamadığı için araştırma dışında bırakılmıştır. "eleştirel düşünme " anahtar sözcüğü ile yapılan taramada konuya ilişkin tez ve makaleye rastlanmamıştır.

Scott 'a göre dokümanların geçerlik ve güvenirlik özelliklerinde dört ölçüt esas alınmaktadır. Bunlar: (1) Dokümanın gerçek olması, (2) doğruluğu içerecek şekilde inanılır olması, (3) taklitten uzak olması ve (4) güncel anlamı içermesidir (aktaran İnci, Akpınar ve Kandır, 2017, s. 499). Dokümanların ölçütlere uygunluğunun saptanmasında araştırmacılar tarafından detaylı incelemeler yapılmıştır. Bu noktada kaynakların gerçekliği ve doğruluğu farklı veritabanlarından ve basılı yayınlardan karşılaştırmalı olarak araştırılarak sağlanmıştır. Aynı zamanda dokümanların taklitten uzak olması ve güncel anlamı içermesi konusunda çalışmalar orijinallik ve güncellik bakımından araştırmacılar tarafından analiz edilmiştir ve 2002-2017 yıllarını kapsayan dokümanlar araştırma kapsamına alınmıştır. Daha sonra seçilen dokümanların içerik analizi yapılmıştır.

Nitel araştırmalarda geçerliliği sağlamada önemli etkenlerin başında, bulunan verilerin ayrıntılı rapor edilerek sonuçlara ulaşılma yollarının açıklanması gelir (Yıldırım, 2010, s. 82). $\mathrm{Bu}$ çalışmada geçerliliği sağlamak için verilerin araştırılma sürecinin ve raporlanan verilerin detaylı biçimde sunulması hedeflenmiştir. Çalışmanın güvenirliğinin, toplanan verilerin 
araştırmacılar tarafından ayrı analiz edilerek incelenip sonrasında birlikte sentezlenerek sağlanması amaçlanmıştır.

Araştırma kapsamına alınan yüksek lisans-doktora tezleri ve makaleler doküman incelemesinin beş aşaması dikkate alınarak toplanmıştır (Şimşek, 2009, s. 43):

(1) Dokümanlara ulaşma olan ilk basamakta ihtiyaç duyulan dokümanlar ve bu dokümanlara nasıl ulaşılacağı belirlenmiştir. Buna göre araştırmada ihtiyaç duyulan dokümanlar düşünme becerileri ve düşünme becerilerini alt becerileri olan problem çözme, yaratıcı düşünme, eleştirel düşünme, karar verme becerilerinden yola çıkılarak saptanmıştır. Kullanılacak olan dokümanlardan yüksek lisans ve doktora tez çalışmalarına Yüksek Öğretim Kurulu Başkanlığı (YÖK) Tez Arşivi ve Google Akademik veri tabanları ile ulaşılmıştır. Makaleler ise Google Akademik veri tabanından tarama yapılarak elde edilmiştir. Belirlenen dokümanlar pdf formatında dosyalanarak bilgisayara kaydedilmiştir.

(2) Orijinalliğin kontrol edilmesinde, araştırmacıların ulaştığı dokümanların veri kaynağı olarak kullanılıp kullanılmayacağı çalışmanın geçerliği ve güvenirliğini sağlamak açısından incelenmiştir. Dokümanların gerçekliği veya sahte olma durumu, üzerlerinde bir değiştirme olup olmadığı araştırmacılar tarafından kontrol edilmiştir. Uygun olmadığı tespit edilen çalışmalar araştırma örnekleminden çıkartılmıştır.

(3) Dokümanların incelenmesi ve anlaşılması, aşamasında araştırmada yer alacak çalışmalar araştırmacılar tarafından anlaşılarak özümsenmiştir. Tez ve makaleler düşünme becerileri ve alt becerileri olan problem çözmeye, yaratıcı düşünmeye, eleştirel düşünmeye ve karar vermeye göre gruplara ayrılmıştır. Sonrasında dokümanların yılı, konusu, yöntemi ve bulgularına yönelik düzenlenip bilgisayara word belgesi olarak kaydedilmiştir.

(4) Verilerin analiz edilmesinde içerik analizine ve betimsel istatistiklere yer verilmiştir. İçerik analizi verileri belli kavramlar ve temalar dahilinde bir araya getirmeyi ve yorumlamayı gerektirir. Araştırmacılar verilerin içerik analizinde, konular ve temaları dikkate alarak betimlemeler ve kodlamalar yapmıştır. Sonrasında göstergelere dayanarak açıklama, çıkarımda ve yorumda bulunma, tartışma aşamaları gerçekleştirilmiştir. Betimsel istatistikler; araştırma kapsamına alınan bilimsel çalışmaların doktora tezi, yüksek lisans tezi, makale olma durumu, temalarda kullanılan frekans ve yüzde gibi etmenler açısından yapılmıştır (Arıkan, 2011, s. 27; Y1ldırım ve Şimşek, 2011, s. 197).

(5) Verilerin kullanılması doküman incelemesinin son basamağıdır. Bu aşamada araştırmada elde edilen bulgular araştırmacılar tarafindan analiz edilip yorumlanmıştır. Literatüre 1şık tutması beklenen bilgiler ve öneriler yer almıştır.

\section{Bulgular ve Tartışma}

Düşünme becerileri kapsamında erken y1llara ait Türkiye'de yapılan çalışmaların dünyaya oranla niceliksel olarak oldukça az olduğu dikkat çekmektedir. Ancak son yıllarda düşünme becerileri ve özellikle alt becerilerine ilişkin erken çocukluk dönemi çalışmalarının sayısında artış olduğu görülmektedir.

Araştırmanın amacı olan erken düşünme becerilerine yönelik Türkiye'de yapılan bilimsel çalışmaların incelenmesi kapsamına alınan araştırmalar doğrudan düşünme becerilerine yönelik çalışmalar ve düşünme becerilerinin; problem çözme becerisi, yaratıcı düşünme becerisi, eleştirel düşünme becerisi, karar verme becerisi alt boyutlarına göre temalandırılmış ve kodlanmıştır. Belirlenen araştırmalar analiz edilmiş ve alan yazın ışığında tartışılmıştır. 
Tablo 1. Araştırma kapsamına alınan ve analiz edilen doktora tezlerinin dağılımı

\begin{tabular}{|c|c|c|c|}
\hline Kod & Tez Adı & Üniversite/İl & Yil \\
\hline DT1 & $\begin{array}{l}\text { Çocuklar İçin Sosyal Beceri Eğitim Programının } 6 \text { Yaş } \\
\text { Çocukların Sosyal Problem Çözme Becerilerine Etkisi }\end{array}$ & $\begin{array}{c}\text { Selçuk } \\
\text { Üniversitesi } \\
\text { Sosyal } \\
\text { Bilimler } \\
\text { Enstitüsü, } \\
\text { Konya }\end{array}$ & 2008 \\
\hline DT2 & $\begin{array}{c}\text { Anasınıfına Devam Eden Altı Yaş Çocuklarının Yaratıcı } \\
\text { Düşünme Becerilerine Drama Eğitiminin Etkisinin } \\
\text { İncelenmesi }\end{array}$ & $\begin{array}{c}\text { Ankara } \\
\text { Üniversitesi } \\
\text { Fen Bilimleri } \\
\text { Enstitüsü, } \\
\text { Ankara }\end{array}$ & 2009 \\
\hline DT3 & $\begin{array}{l}\text { Proje Yaklaşımının Anasınıfına Devam Eden Çocukların } \\
\text { Problem Çözme Becerilerine Etkisinin İncelenmesi }\end{array}$ & $\begin{array}{c}\text { Ankara } \\
\text { Üniversitesi } \\
\text { Fen Bilimleri } \\
\text { Enstitüsü, } \\
\text { Ankara }\end{array}$ & 2012 \\
\hline DT4 & $\begin{array}{c}\text { Sosyal Problem Çözme Eğitiminin Altı Yaş Çocuklarının } \\
\text { Matematik Becerilerine Etkisi }\end{array}$ & $\begin{array}{c}\text { Selçuk } \\
\text { Üniversitesi } \\
\text { Sosyal } \\
\text { Bilimler } \\
\text { Enstitüsü, } \\
\text { Konya }\end{array}$ & 2013 \\
\hline DT5 & $\begin{array}{c}\text { Psikososyal Gelişim Temelli Eğitim Programının } \\
\text { Anasınıfına Devam Eden Çocukların Duygusal Zekalarına } \\
\text { ve Problem Çözme Becerilerine Etkisi }\end{array}$ & $\begin{array}{c}\text { Gazi } \\
\text { Üniversitesi } \\
\text { Eğitim } \\
\text { Bilimleri } \\
\text { Enstitüsü, } \\
\text { Ankara }\end{array}$ & 2015 \\
\hline DT6 & $\begin{array}{c}\text { Sosyal Beceri Eğitimi Programı ile Desteklenmiş Montessorı } \\
\text { Yönteminin Anaokulu Çocuklarının Duyguları Anlama ve } \\
\text { Sosyal Problem Çözme Becerilerine Etkisi }\end{array}$ & $\begin{array}{c}\text { Selçuk } \\
\text { Üniversitesi } \\
\text { Sosyal } \\
\text { Bilimler } \\
\text { Enstitüsü, } \\
\text { Konya }\end{array}$ & 2015 \\
\hline DT7 & $\begin{array}{c}\text { Okul Öncesi Çocukların Problem Çözme Sürecinde } \\
\text { Teknoloji Destekli Şematik Düzenleyicilerin Kullanımına } \\
\text { Yönelik Bir Durum Çalışması }\end{array}$ & $\begin{array}{c}\text { Gazi } \\
\text { Üniversitesi } \\
\text { Eğitim } \\
\text { Bilimleri } \\
\text { Enstitüsü, } \\
\text { Ankara }\end{array}$ & 2016 \\
\hline DT8 & $\begin{array}{l}\text { 48-72 Aylık Çocuklara Yönelik Sosyal Problem Çözme } \\
\text { Becerileri Ölçeği'nin Geliştirilmesi }\end{array}$ & $\begin{array}{c}\text { Marmara } \\
\text { Üniversitesi } \\
\text { Eğitim } \\
\text { Bilimleri } \\
\text { Enstitüsü, } \\
\text { İstanbul }\end{array}$ & 2016 \\
\hline DT9 & $\begin{array}{c}\text { Problem Çözme Eğitim Programının Anasınıfina Devam } \\
\text { Eden Çocukların Problem Çözme Becerileri İle Kişiler Arası } \\
\text { Problem Çözme Becerilerine Etkisi }\end{array}$ & $\begin{array}{c}\text { Gazi } \\
\text { Üniversitesi } \\
\text { Eğitim } \\
\text { Bilimleri } \\
\text { Enstitüsü, } \\
\text { Ankara }\end{array}$ & 2016 \\
\hline
\end{tabular}


Erken düşünme becerileri ve ilişkili becerilerden; problem çözme becerisi, yaratıcı düşünme becerisi, eleştirel düşünme becerisi ve karar verme becerisine yönelik yapılan araştırmada bulunan dokuz doktora tez çalışması Tablo 1'de yer almaktadır. Veri tabanlarından "düşünme becerisi", "Eleştirel düşünme " ve "Karar verme" anahtar sözcükleri ile yapılan taramada doktora tezine rastlanmamıştır. "Yaratıcı düşünme" anahtar sözcüğü ile yapılan taramada bir doktora tezi, "problem çözme " anahtar sözcüğü ile yapılan taramada sekiz doktora tezi tespit edilmiştir (Dereli, 2008; Can Yaşar, 2009; Oğuz, 2012; Giren, 2013; Kayıl1, 2015; Şahin, 2015; Alemdar Coşkun, 2016; Çetin, 2016; Yılmaz, 2016).

Doktora tez konuları yıllara göre incelendiğinde 2002-2007 yıllarında erken düşünme becerileri ile doğrudan ilişkili çalışma bulunamamıştır. 2008 yılından itibaren araştırmaların yapıldığı görülmektedir. Yapılan araştırmalar erken dönem yaratıcı düşünme ve problem çözme becerileriyle ilişkilidir.

Erken çocuklukta problem çözme çalışmaların çocukların problem çözme becerisisüreci ve bilişsel gelişimle ilişkili olan sosyal problem çözmeye yönelik olduğu görülmektedir. Çetin $(2016$, s. 2) çalışmasında bireyin sahip olması gereken beceriler olarak nitelendirdiği problem çözme becerisini, üst düzey düşünme becerilerinin temeli olarak ele almıştır. Bu durum ise erken düşünme becerileri konusunda problem durumu ve alternatif çözüm arayışı bileşenlerinin sahip olduğu kritik rol ile ilişkilendirilebilir. Nitekim bu kritik rolün etkisiyle günümüzde düşünme becerilerini geliştirmeye ve desteklemeye yönelik çalışmalarda problem çözme ve problemlere nitelik-nicelik bakımından etkili çözümler bulma etkinlikleri yaygınlaşmaktadır.

Erken çocukluk döneminde yaratıcı düşünme becerisi ile ilgili çalışmalar son derece az olduğundan bu çalışmalara yönelik boşluk dikkat çekmektedir. Can Yaşar (2009, s. 28) araştırmasında çocukların bilgiyi yaratıcı bir biçimde düzenlediği ve bu düzenlemenin en iyi düzeyine çocukluğun ilk yıllarında ulaşıldığı bilgisine yer vermektedir.

Araştırmada analiz edilen doktora tezlerinin büyük kısmı (DT1, DT3, DT4, DT5, DT6, DT7, DT8, DT9) erken düşünme becerilerinden problem çözme becerisini vurgulamaktadır. Erken dönemde problem çözme becerilerine yönelik olan doktora tezlerinin bir kısmı (DT1, DT4, DT6, DT8, DT9) sosyal problem çözme ve kişiler arası problem çözme boyutlarına değinmektedir. İlgili araştırmalarda sosyal/kişiler arası problem çözme becerilerini destekleyici eğitim programı çalışmalarına ve ölçek geliştirme çalışmasına, farklı yöntemlerin bu becerilere etkisine ve bu boyutların diğer becerilere etkisine ilişkin çalışmalara yer verildiği görülmektedir. Araştırmaların ortak vurgusunun bu becerilerin; yaşamın ilk yıllarından itibaren desteklenmesi gereken, kazanılıp/kazanılamamasının yaşamın diğer gelişim dönemlerine olumlu/olumsuz etkisi olan ve yaşam boyu süren beceriler olmasıdır. Ayrıca çalışmaların çoğunda çocuklarda sosyal beceriler ile problem çözme gibi bilişsel becerilerin ilişkisel olarak incelendiği görülmektedir. İlgili çalışmalar analiz edildiğinde çocuklarda bilişsel ve akademik beceriler ile sosyal beceriler arasında olumlu ilişki olduğu erken çocukluk döneminde sosyal beceri eğitimi alan çocukların sosyal problem çözme becerilerinde pozitif ilerleme kaydedildiği söylenebilir. Erken dönemde problem çözme becerilerine yönelik olan diğer doktora tezlerinin (DT3, DT5, DT7) bir tanesi programa dayalı, bir diğeri yaklaşıma dayalı ve bir tanesi de teknoloji temelli şematik düzenleyicilerin etkisine yönelik problem çözme becerisini incelemiştir. Tezlerde ortak vurgu çocuklarda problem çözmenin küçük yaşlardan itibaren görüldüğü ve desteklenebilir bir beceri olduğudur. Çünkü çocuklar için her durum, her eylem, her oyun problem olabilir. Ayrıca çocuklara firsat verildiği zaman probleme ilişkin fikirlerini ortaya koyma becerisine sahip oldukları belirtilmekle birlikte bu konuda çevrenin çocuğa karşı tutumunun önemi de vurgulanmaktadır. Bununla birlikte çalışmalarda çocuklarda problem çözme sürecinin desteklenmesi konusunda onlarla problemin varlığına ilişkin konuşmanın yani problemi tanımlamanın son derece önemli olduğu bilgisi yer almaktadır. 
Araştırmada analiz edilen doktora tezlerinin diğer kısmını (DT2) erken düşünme becerilerinden yaratıcı düşünme becerisi oluşturmaktadır.

Araştırma kapsamında yer alan doktora tezleri yöntemsel olarak incelendiğinde ise; çalışmaların birçoğunun deneme modelinde yapıldığ 1 ancak nitel ve nicel verilerin yer aldığ 1 karma modelde de araştırmanın yer aldığı görülmektedir.

Araştırma kapsamında incelenen doktora tezlerinin yıllara göre dağılımı Şekil 1'de gösterilmiştir.

Şekil 1. Doktora tezlerinin yıllara göre dağılımı

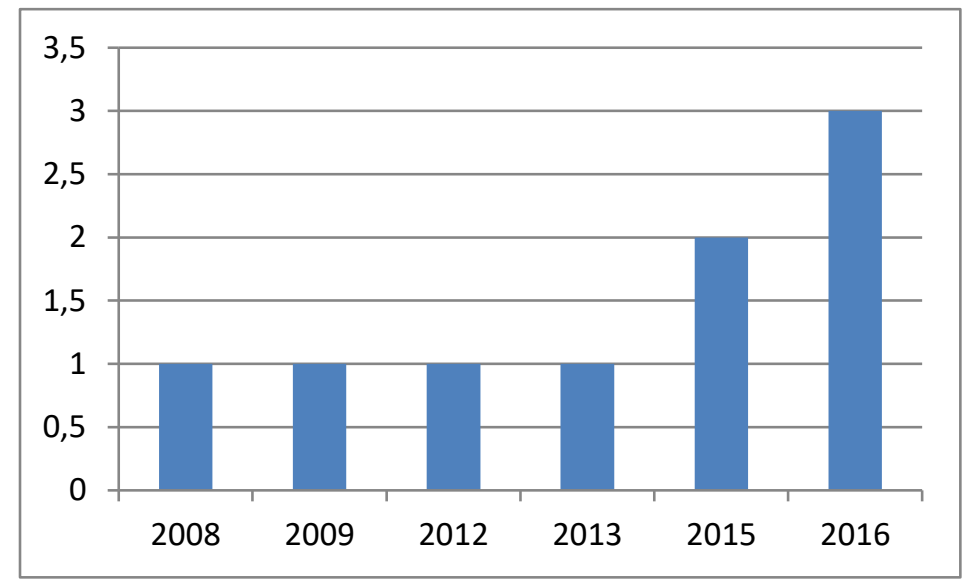

Şekil 1 incelendiğinde araştırma kapsamına alınan doktora tezlerinin \%11,1'inin 2008 y1lına, \%11,1'inin 2009 y1lına, \%11,1'inin 2012 y1lına,\%11,1'inin 2013 y1lına, \%22,2'sinin 2015 yılına, \%33,3'ünün 2016 yılına ait olduğu görülmektedir.

Araştırma kapsamına alınan doktora tezlerinin temalara göre dağılımı Şekil 2'de gösterilmiştir.

Şekil 2. Doktora tezlerinin temalara göre dağılımı

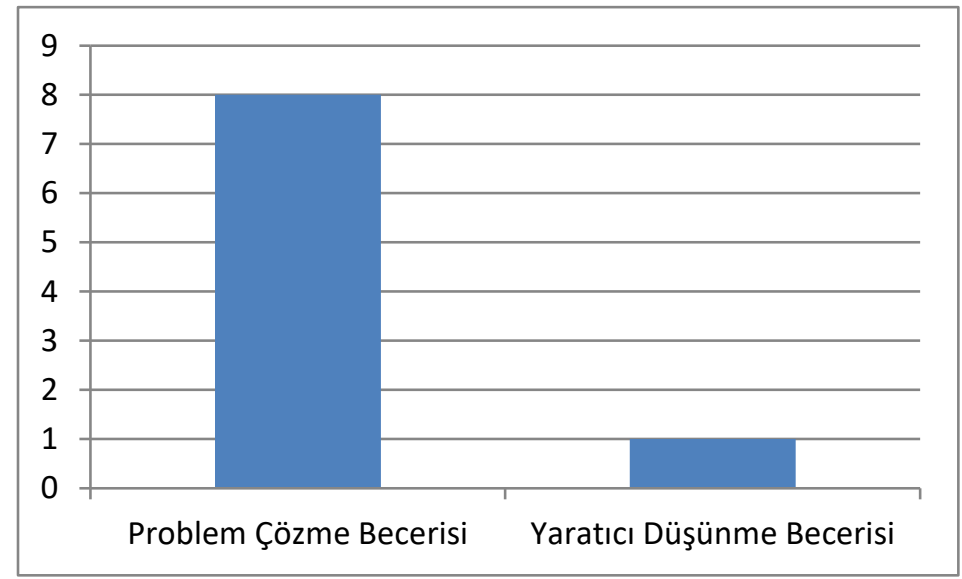

Şekil 2 incelendiğinde araştırma kapsamına alınan doktora tezlerinin tema bakımından \%11,1'ini yaratıcı düşünme becerisinin, \%88,9'unu problem çözme becerisinin oluşturduğu görülmektedir. 
Tablo 2. Araştırma kapsamına alınan ve analiz edilen yüksek lisans tezlerinin dağılımı

\begin{tabular}{|c|c|c|c|}
\hline Kod & 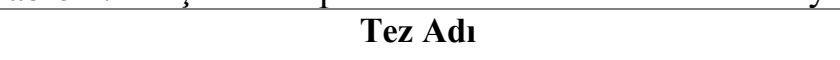 & Üniversite/İl & Yıl \\
\hline T1 & $\begin{array}{l}6 \text { Yaş Grubu Anasınıfı Öğrencilerinin Problem Çözme } \\
\text { Becerilerinin Karşılaştırmalı Olarak İncelenmesi }\end{array}$ & $\begin{array}{l}\text { Abant İzzet Baysal } \\
\text { Üniversitesi Sosyal } \\
\text { Bilimler Enstitüsü, } \\
\text { Bolu }\end{array}$ & 2007 \\
\hline $\mathbf{T 2}$ & $\begin{array}{l}\text { İlköğretim Birinci Sınıf Öğrencilerinin Problem Çözme } \\
\text { Stratejilerini Kullanabilme Düzeyleri }\end{array}$ & $\begin{array}{l}\text { UludağÜniversitesi } \\
\text { Sosyal Bilimler } \\
\text { Enstitüsü, Bursa }\end{array}$ & 2009 \\
\hline T3 & $\begin{array}{l}\text { Erken Çocukluk Dönemindeki Çocukların (60-72 Ay) } \\
\text { Düşünme Düzeylerinin ve Okul Öncesi Öğretmenlerinin } \\
\text { Düşünme Eğitimi ile İlgili Tutumlarının İncelenmesi }\end{array}$ & $\begin{array}{l}\text { Çanakkale Onsekiz } \\
\text { Mart Üniversitesi } \\
\text { Sosyal Bilimler } \\
\text { Enstitüsü, } \\
\text { Çanakkale }\end{array}$ & 2010 \\
\hline T4 & $\begin{array}{c}6 \text { Yaş Grubu Çocuklarda Genel Problem Çözme } \\
\text { Becerilerini Değerlendirme Ölçeğinin Geliştirilmesi, } \\
\text { Geçerlik ve Güvenirlik Çalışmaları }\end{array}$ & $\begin{array}{l}\text { Gazi Üniversitesi } \\
\text { Eğitim Bilimleri } \\
\text { Enstitüsü, Ankara }\end{array}$ & 2012 \\
\hline T5 & $\begin{array}{l}\text { Montessori Yönteminin Okul Öncesi Dönemde } \\
\text { Öğrencilerin Yaratıcı Düşünmelerine Etkisi }\end{array}$ & $\begin{array}{c}\text { Zonguldak } \\
\text { Karaelmas } \\
\text { Üniversitesi Sosyal } \\
\text { Bilimler Enstitüsü, } \\
\text { Zonguldak }\end{array}$ & 2012 \\
\hline T6 & $\begin{array}{l}\text { 60-72 Aylık Çocukların Duyguları Anlama Becerilerinin } \\
\text { Sosyal Problem Çözme Becerilerine Etkisinin İncelenmesi }\end{array}$ & $\begin{array}{l}\text { Selçuk } \\
\text { Üniversitesi Sosyal } \\
\text { Bilimler Enstitüsü, } \\
\text { Konya }\end{array}$ & 2012 \\
\hline T7 & $\begin{array}{l}\text { 5-6 Yaş Grubu Çocukların Akran İlişkilerinin Sosyal } \\
\text { Problem Çözme Becerisi Açısından İncelenmesi }\end{array}$ & $\begin{array}{l}\text { Selçuk } \\
\text { Üniversitesi Sosyal } \\
\text { Bilimler Enstitüsü, } \\
\text { Konya }\end{array}$ & 2013 \\
\hline T8 & $\begin{array}{c}\text { Reggıo Emılıa Temelli Projelerin Anaokuluna Giden } \\
\text { Çocukların Yaratıcı Düşünme Becerilerine Etkisinin } \\
\text { İncelenmesi }\end{array}$ & $\begin{array}{c}\text { Hacettepe } \\
\text { Üniversitesi } \\
\text { EğitimBilimleri } \\
\text { Enstitüsü, Ankara }\end{array}$ & 2014 \\
\hline T9 & $\begin{array}{c}\text { Yönlendirilmiş Beyin Fırtınası (Scamper) Tekniğine } \\
\text { Dayalı Eğitimin Beş Yaş Çocuklarının Problem Çözme } \\
\text { Becerilerine Etkisinin İncelenmesi }\end{array}$ & $\begin{array}{c}\text { Hacettepe } \\
\text { Üniversitesi } \\
\text { EğitimBilimleri } \\
\text { Enstitüsü,Ankara }\end{array}$ & 2014 \\
\hline T10 & $\begin{array}{c}\text { 60-72 Aylık Çocukların Sosyal Problem Çözme } \\
\text { Becerilerinin ve Akran İlişkilerinin İşitsel Muhakeme ve } \\
\text { İşlem Becerileri Açısından İncelenmesi }\end{array}$ & $\begin{array}{l}\text { Selçuk } \\
\text { Üniversitesi Sosyal } \\
\text { Bilimler Enstitüsü, } \\
\text { Konya }\end{array}$ & 2014 \\
\hline T11 & $\begin{array}{c}\text { Annelerin Duygu Sosyalleştirme Davranışları İle } \\
\text { Çocukların Benlik Algısı ve Sosyal Problem Çözme } \\
\text { Becerilerinin İncelenmesi }\end{array}$ & $\begin{array}{l}\text { Gazi Üniversitesi } \\
\text { Eğitim Bilimleri } \\
\text { Enstitüsü, Ankara }\end{array}$ & 2015 \\
\hline T12 & $\begin{array}{l}\text { Öğretmen ve Ebeveyn Tutumlarının Okul Öncesi Dönem } \\
\text { Çocuklarının Problem Çözme Becerilerine Etkisinin } \\
\text { İncelenmesi }\end{array}$ & $\begin{array}{l}\text { Karabük } \\
\text { Üniversitesi Sağlık } \\
\text { Bilimleri } \\
\text { Enstitüsü, Karabük }\end{array}$ & 2015 \\
\hline
\end{tabular}


Erken düşünme becerileri ve ilişkili becerilerden; problem çözme becerisi, yaratıcı düşünme becerisi, eleştirel düşünme becerisi ve karar verme becerisine yönelik yapılan araştırmada bulunan on iki yükssek lisans tez çalışması Tablo 2'de yer almaktadır. Veri tabanlarından "eleştirel düşünme " anahtar sözcüğü ile yapılan taramada yüksek lisans tezine ulaşılamamıştır. "düşünme becerisi " anahtar sözcüğü ile yapılan taramada bir, "yaratıcı düşünme " anahtar sözcügü ile yapılan taramada iki, "problem çözme" anahtar sözcüğü ile yapılan taramada dokuz, "karar verme " anahtar sözcügü ile yapılan taramada bir yüksek lisans tezi tespit edilmiştir (Tavlı, 2007; Çelebioğlu, 2009; Mutlu, 2010; Arslan, 2012; Şahintürk, 2012; Y1lmaz, 2012; Özmen, 2013; Akar Gençer, 2014; Akkaya Ersan, 2014; Yiğitalp, 2014; Begde, 2015; Özkan, 2015). Yüksek lisans tezleri kapsamında yer alan karar verme becerisine ilişkin Çok Amaçlı Karar Verme Konusunda Yeni Yaklaşımlar ve Okul Öncesi Ĕ̈itime İlişkin Bir Uygulama konulu tez taramada görülmekle birlikte tezin kendisine ve erken karar verme becerisine yönelik verilerine ulaşılamadığı için araştırma dışında bırakılmıştır (İpekçi Çetin, 2002).

Yüksek lisans tez konuları yıllara göre incelendiğinde erken düşünme becerileri ile doğrudan ilişkili 2002-2007 yılları arasında çalışma bulunamamıştır. 2007 yılında bir yüksek lisans tezi bulunmuştur. Özellikle 2010 yılından itibaren araştırmaların artmaya başladığ görülmektedir.

Erken dönemde düşünme ile doğrudan ilişkili olan Mutlu'nun (2010, s. 23) araştırmasında çocukların erken çocuklukta düşünme eylemi ile ilgilendikleri, sorgulama yaptıkları ve orijinal düşünceler üretebildikleri yer almaktadır. Bu durum çocukların gelişimsel özelliklerinden merak duygusundan kaynaklanabilir. Çünkü erken çocukluk yıllarında çocuklar henüz keşfettikleri çevreye ve olaylara ilgili, onları keşfetmeye meraklıdırlar. Çocuklar bu merak duygusunu düşünerek, soru sorarak, sorgulama ve muhakeme yaparak eylemleştirirler. İşte bu noktada düşünme becerileri devreye girer. Çocukları düşünmeye teşvik etmede ve düşünme becerilerini desteklemede erken çocukluk döneminde yaşadıkları deneyimler son derece önemlidir.

Düşünme becerilerinin geliştirilmesinde önemli unsurlardan biri de çocukların karşılaştıkları problemleri çözme becerisi kazanmasıdır. Araştırmanın örnekleminde yer alan problem çözmeye yönelik çalışmaların ortak yönü bu becerinin erken yaşlarda kazandırılmasının kritik rol oynamasıdır.

Çocuklar için problem çözme becerisi gibi önemli bir diğer beceri olan yaratıcı düşünme becerisi ile ilgili Tablo 2 'de yer alan araştırmalar farklı okul öncesi yaklaşımlar ile yaratıcı düşünme becerisi arasında ilişki kurmuştur. $\mathrm{Bu}$ araştırmaların ortak yönü ise ele aldığ 1 yaklaşımın okul öncesi dönem yaratıcı düşünme becerisine etkisini araştırılmasıdır.

Araştırmada analiz edilen yüksek lisans tezlerinin büyük kısmının (T1, T2, T4, T6, T7, T9, T10,T11,T12) erken düşünme becerilerinden problem çözme becerisini vurguladı̆̆ görülmektedir. Erken dönemde problem çözme becerilerine yönelik olan yüksek lisans tezlerinin bir kısmı (T6, T7, T10, T11) sosyal problem çözme boyutuna ilişkindir. Erken dönemde problem çözme becerilerine yönelik olan diğer yüksek lisans tezlerinin (T1, T2, T4, T9, T12) bir tanesi karş1laştırmalı, bir tanesi düzeysel, bir diğeri tekniğe dayalı, bir tanesi ögretmen ve ebeveyn tutumunun etkisine yönelik, bir tanesi de geçerlik güvenirlik belirlemeye ilişkin problem çözme becerisini incelemiştir. Araştırmada analiz edilen yüksek lisans tezlerinin diğer kısmını (T5, T8) erken düşünme becerilerinden yaratıcı düşünme becerisi oluşturmaktadır. Araştırmada analiz edilen yüksek lisans tezleri arasında (T4) doğrudan erken düşünme becerilerine yönelik olan bir çalışma da yer almaktadır.

Araştırma kapsamında yer alan yüksek lisans tezleri yöntemsel olarak incelendiğinde ise; çalışmaların yarısından çoğunun tarama modelinde olduğu ancak nicel ve nitel verilerin yer aldığı karma model de araştırmaların da bulunduğu görülmektedir. 
Araştırma kapsamında incelenen yüksek lisans tezlerinin yıllara göre dağılımı Şekil 3’te gösterilmiştir.

Şekil 3. Yüksek lisans tezlerinin yıllara göre dağılımı

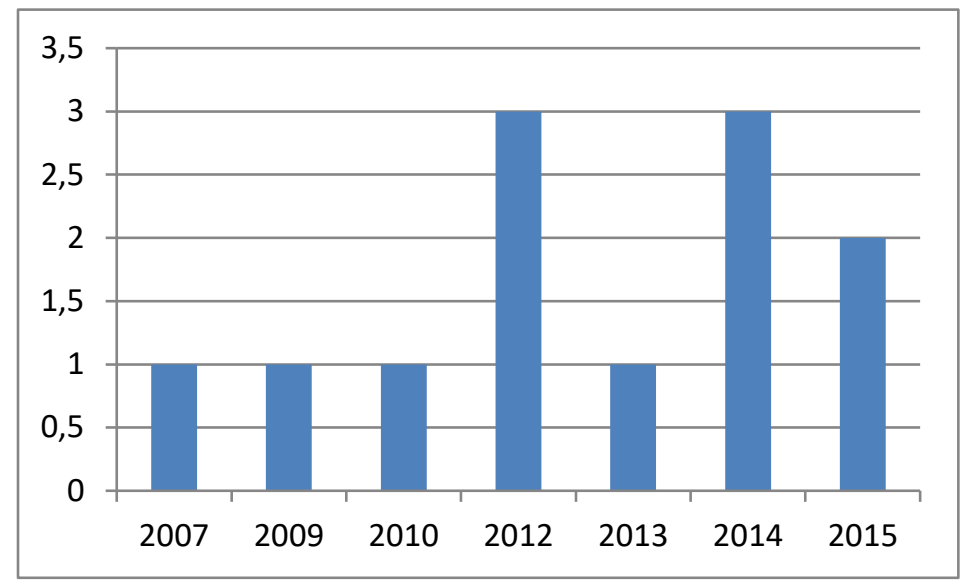

Şekil 3 incelendiğinde araştırma kapsamına alınan yüksek lisans tezlerinin \%8,4'ünün 2007 y1lına, \%8,4'ünün 2009 yılına, \%8,4'ünün 2010 yılına, \%25'inin 2012 y1lına, \%8,4'ünün 2013 yılına, \%25'inin 2014 yılına, \%16,7'sinin 2015 yılına ait olduğu görülmektedir.

Araştırma kapsamına alınan yüksek lisans tezlerinin temalara göre dağılımı Şekil 4’te gösterilmiştir.

Şekil 4. Yüksek lisans tezlerinin temalara göre dağılımı

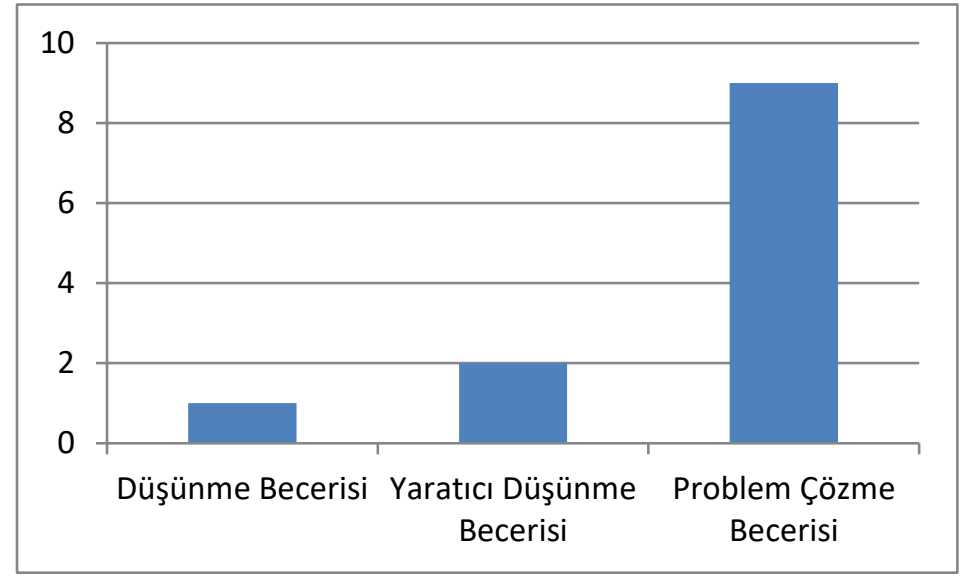

Şekil 4 incelendiğinde araştırma kapsamında incelenen yüksek lisans tezlerinin temalara göre $\% 8,3$ 'ünü düşünme becerisi, $\% 16,6$ 'sını yaratıcı düşünme becerisi ve $\% 75^{\prime}$ ini problem çözme becerisi oluşturmaktadır. 
Tablo 3. Araștırma kapsamına alınan ve analiz edilen makalelerin dağılımı

\begin{tabular}{|c|c|c|}
\hline Kod & Makale Adı & Yil \\
\hline M1 & $\begin{array}{l}\text { Okul Öncesi Dönemde Kişiler Arası Bilişsel Problem Çözme } \\
\text { Becerilerinin Geliştirilmesi }\end{array}$ & 2005 \\
\hline M2 & $\begin{array}{c}\text { Okul Öncesi Dönemde Düşünme Becerilerinin Gelişmesinde } \\
\text { Yaratıcı Bir Süreç Olarak Drama }\end{array}$ & 2006 \\
\hline M3 & $\begin{array}{c}\text { Annelere İlişkin Bazı Değişkenlerin 5-6 Yaş Çocuklarının } \\
\text { Yaratıcı Düşüncelerine Etkisi }\end{array}$ & 2007 \\
\hline M4 & $\begin{array}{l}\text { Erken Çocukluk Döneminde Düşünme Becerilerinden } \\
\text { Planlama ve Derin Düșünmenin Geliștirilmesi }\end{array}$ & 2007 \\
\hline M5 & $\begin{array}{c}\text { Yaratıcı Düşünme Becerilerinde Okul Öncesi Eğitimin } \\
\text { Etkisi }\end{array}$ & 2010 \\
\hline M6 & $\begin{array}{c}\text { Altı Yaş Çocuklarının Yaratıcı Düşünme Becerilerine } \\
\text { Sosyo-Ekonomik Düzey ve Anne Baba Öğrenim Düzeyinin } \\
\text { Etkisinin İncelenmesi }\end{array}$ & 2011 \\
\hline M7 & $\begin{array}{c}\text { Çocuklar İçin Sosyal Problem Çözme Ölçeği'nin } 6 \text { Yaş } \\
\text { Grubu İçin Türkiye Uyarlaması ve Okul Öncesi Davranış } \\
\text { Problemleri ile Sosyal Problem Çözme Becerileri Arasındaki } \\
\text { İlişkiler }\end{array}$ & 2013 \\
\hline
\end{tabular}

Erken düşünme becerileri ve ilişkili becerilerden; problem çözme becerisi, yaratıcı düşünme becerisi, eleştirel düşünme becerisi ve karar verme becerisine yönelik yapılan araştırmada bulunan yedi makale çalışması Tablo3'te yer almaktadır. Veri tabanlarından "eleştirel düşünme" ve "karar verme" anahtar sözcükleri ile yapılan taramada araştırma ile doğrudan ilişkili makale bulunamamıştır. "Düşünme becerisi" anahtar sözcüğü ile yapılan taramada bir, "yaratıcı düşünme" anahtar sözcügü ile yapılan taramada dört , "problem çözme " anahtar sözcüğü ile yapılan taramada iki makale tespit edilmiştir (Anlıak ve Dinçer, 2005; Can Yaşar ve Aral, 2010; Can Yaşar ve Aral, 2011; Dağlığlu ve Çakır, 2007; Dereli İman, 2013; Erbay ve Çağdaş, 2007; Tuğrul, 2006).

Makale konuları yıllara göre incelendiğinde 2002-2004 yılları arasında erken düşünme becerileri ile doğrudan ilişkili çalışma bulunamamıştır. Literatür taramasında 2005, 2006 yıllarına ait birer makale, 2007 yılına ait iki makale ve 2010, 2011 ve 2013 yıllarında birer makale tespit edilmiştir. Yapılan araştırmalar erken düşünme becerisi ile erken çocukluk dönemi yaratıcı düşünme ve problem çözme becerileriyle ilişkilidir.

Tablo 3'te yer alan makalelerden yaratıcı düşünme becerisine yönelik çalışmalar incelendiğinde; çocuklarda yaratıcı düşünme becerisine yönelik makalelerden ikisi aileye ilişkin farklı değişkenlerin etkisine, biri okul öncesi eğitimin etkisine yer vermiştir. Bir diğer makalede ise çocukların düşünme becerisinde yaratıcı süreçlerden dramanın etkisi anlatılmıştır.

Tablo 3'te yer alan makalelerden problem çözme becerisine yönelik olanlar incelendiğinde çocuklarda, kişilerarası bilişsel problem çözme ve sosyal problem çözme boyutlarının incelendiği görülmektedir. Literatür incelendiğinde sosyal problem çözme ve kişilerarası problem çözme kavramları birçok kaynakta birbiri yerine kullanılmaktadır. Ancak bazı kaynaklarda sosyal problem çözme ve kişilerarası problem çözme yetileri problem çözme becerisinin farklı boyutları olarak incelenmiştir. 
Araştırmada analiz edilen makalelerin büyük k1smının (M2, M3, M5, M6) erken düşünme becerilerinden yaratıcı düşünme becerisini vurguladığ 1 görülmektedir. Araştırmada analiz edilen makalelerin diğer kısmının (M1,M7) erken düşünme becerilerinden problem çözme becerisini vurguladığ 1 görülmektedir. Erken dönemde problem çözme becerilerine yönelik makaleler sosyal problem çözme ve kişiler arası problem çözme boyutuna ilişkindir. Araştırmada analiz edilen makaleler arasında (M4) doğrudan erken düşünme becerilerine yönelik olan bir çalışma da yer almaktadır.

Araştırma kapsamında incelenen makalelerin yıllara göre dağılımı Şekil 5'te gösterilmiştir.

Şekil 5. Makalelerin yıllara göre dağılımı

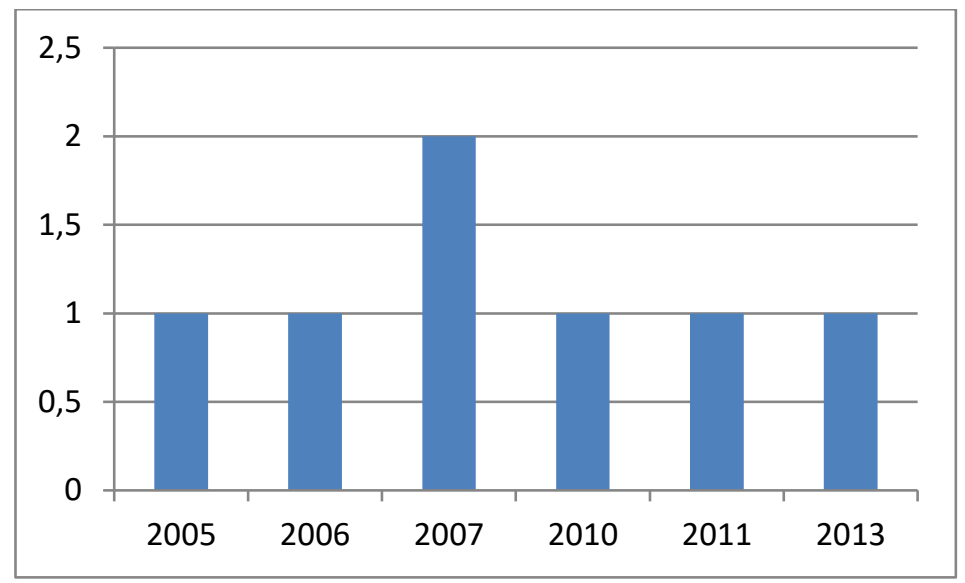

Şekil 5 incelendiğinde araştırma kapsamına alınan makalelerin \%14,3'ünün 2005 yılına, \%14,3'ünün 2006 yılına, \%28,5'inin 2007 yılına, \%14,3'ünün 2010 yılına, \%14,3'ünün 2011 yılına, \%14,3’ünün 2013 yılına ait olduğu görülmektedir.

Araştırma kapsamında incelenen makalelerin temalara göre dağılımı Şekil 6'da gösterilmiştir.

Şekil 6. Makalelerin temalara göre dağılımı

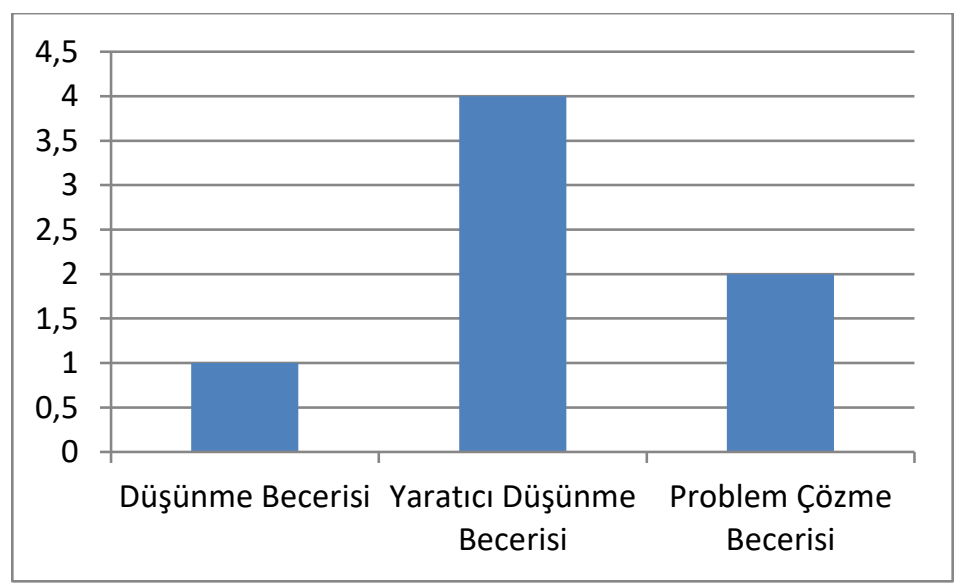

Şekil 6 incelendiğinde araştırma kapsamına alınana makalelerin temalara göre \%14,3’ü düşünme becerisi, \%28,6'sı problem çözme becerisi, \%57,1'i yaratıcı düşünme becerisi temasından oluşmaktadır. 


\section{Sonuç ve Öneriler}

Araştırma kapsamında yapılan analiz sonuçlarından yola çıkılarak erken düşünme becerilerine ilişkin bilimsel çalışmaların yıllar içinde daha da önem kazandığ 1 söylenebilir. Çeşitli disiplinlerin erken düşünme becerilerini farklı boyutlardan ele almış olması literatürü zenginleştirmektedir ancak yeterli görülmemektedir. Erken düşünme becerilerine ilişkin daha fazla sayıda bilimsel araştırmaya gereksinim duyulmaktadır.

Erken düşünme becerilerine yönelik Türkiye'de 2002-2017 yıllarında Türkçe yapılan bilimsel çalışmaların incelenmesini amaçlayan bu araştırmadan elde edilen sonuçlara ilişkin öneriler aşağıda verilmiştir:

- Erken problem çözme boyutuna yönelik lisansüstü tezlerin daha fazla sayıda olduğundan hareketle özellikle erken çocukluk döneminde eleştirel düşünme ve karar verme becerilerine ilişkin daha fazla araştırma yapılabilir.

- Düşünme becerileri birbiri ile ilişkili birçok beceriyi kapsadığından erken düşünme becerilerine yönelik tüm alt becerileri kapsayıcı bilimsel araştırmalara yer verilebilir.

- Nitel ve nicel veriyi dikkate alan karma desenlerde araştırmalar yapılabilir.

- Erken düşünme becerilerinin farklı disiplinlerle ilişkilendirilmesine yönelik daha fazla araştırma yapılabilir.

- Farklı yaş gruplarındaki çocukların düşünme becerisini belirlemeye yönelik ölçme araçları geliştirilebilir.

\section{Kaynakça}

*Akar Gençer, A. (2014). Reggıo Emılıa temelli projelerin anaokuluna giden çocukların yaratıcı düşünme becerilerine etkisinin incelenmesi (Yüksek lisans tezi). Erişim adresi: https://scholar.google.com.tr/scholar?hl=tr\&as_sdt=0\%2C5\&q=Regg\%C4\%B1o+Em\%C4\% $\mathrm{B} 11 \% \mathrm{C} 4 \% \mathrm{~B} 1 \mathrm{a}+$ temelli+projelerin+anaokuluna+giden+\% $\mathrm{C} 3 \% \mathrm{~A} 7$ ocuklar\%C $4 \% \mathrm{~B} 1 \mathrm{n}+\mathrm{yarat} \%$ $\mathrm{C} 4 \% \mathrm{~B} 1 \mathrm{c} \% \mathrm{C} 4 \% \mathrm{~B} 1+\mathrm{d} \% \mathrm{C} 3 \% \mathrm{BC} \% \mathrm{C} 5 \% 9 \mathrm{~F} \% \mathrm{C} 3 \% \mathrm{BCnme}+$ becerilerine+etkisinin+incelenmesi $+\& \mathrm{btnG}=$.

Akbaba, A. ve Kaya, B. (2015). Okul öncesi öğrencilerinin düşünme becerilerinin gelişmesine yönelik öğretmen görüşleri. Elektronik Sosyal Bilimler Dergisi, 14(55), 148-160.

*Akkaya Ersan, G. (2014). 60-72 Aylık çocukların sosyal problem çözme becerilerinin ve akran ilişkilerinin işitsel muhakeme ve işlem becerileri açısından incelenmesi (Yüksek lisans tezi). Erişim adresi: https://scholar.google.com.tr/scholar?hl=tr\&as_sdt=0\%2C5\&q=6072+Ayl\%C4\%B1k+\%C3\%A7ocuklar\%C4\%B1n+sosyal+problem+\%C3\%A7\%C3\%B6zme +becerilerinin+ve+akran+ili\%C5\%9Fkilerinin+i\%C5\%9Fitsel+muhakeme+ve+i\%C5\%9Fle $\mathrm{m}+$ becerileri+a $\% \mathrm{C} 3 \% \mathrm{~A} 7 \% \mathrm{C} 4 \% \mathrm{~B} 1 \mathrm{~s} \% \mathrm{C} 4 \% \mathrm{~B} 1 \mathrm{ndan}+\mathrm{incelenmesi}+\% 28 \mathrm{Y} \% \mathrm{C} 3 \% \mathrm{BCksek}+$ lisa ns+tezi\%29.++\&btnG=.

*Alemdar Coşkun, M. (2016). Problem çözme eğitim programının anasınıfina devam eden çocukların problem çözme becerileri ile kişiler arası problem çözme becerilerine etkisi (Doktora tezi). Erişim adresi: https://tez.yok.gov.tr/UlusalTezMerkezi/tezSorguSonuc Yeni.jsp .

*Anlıak, Ş. ve Dinçer, Ç. (2005). Okul öncesi dönemde kişiler arası bilişsel problem çözme becerilerinin geliştirilmesi. Eğitim Araştırmaları, (20), 122-134.

*Anlıak, Ş. ve Dinçer B. (2006). Okul öncesi dönemde düşünme becerilerinin gelişmesinde yaratıcı bir süreç olarak drama. Yaratıcı Drama Dergisi, 1(2), 99-110.

Arıkan, R. (2011). Araştırma yöntem ve teknikleri, Ankara: Nobel Yayıncılık. 
*Arslan, A. (2012). 6 yaş grubu çocuklarda genel problem çözme becerilerini değerlendirme ölçeğinin geliştirilmesi, geçerlik ve güvenirlik çalışmaları (Yüksek lisans tezi). Erişim adresi: https://tez.yok.gov.tr/UlusalTezMerkezi/tezSorguSonucYeni.jsp.

Ay, G. K. (2014). Okul öncesi eğitim kurumları yönetici ve öğretmenlerinin düşünme becerilerinin ögretimine yönelik görüşleri (Yüksek lisans tezi). Erişim adresi: https://www.ulusaltezmerkezi.net/okul-oncesi-egitim-kurumlari-yonetici-ve-ogretmenlerinin -dusunme-becerilerinin-ogretimine-yonelik-gorusleri/122/.

*Begde, Z. (2015). Öğretmen ve ebeveyn tutumlarının okul öncesi dönem çocuklarının problem çözme becerilerine etkisinin incelenmesi (Yüksek lisans tezi). Erişim adresi: https://scholar.google.com.tr/scholar?hl=tr\&as_sdt=0\%2C5\&q=\%C3\%96\%C4\%9Fretmen+v e+ebeveyn+tutumlar\%C4\%B1n\%C4\%B1n+okul+\%C3\%B6ncesi+d\%C3\%B6nem+\%C3\%A 7ocuklar\%C4\%B1n\%C4\%B1n+problem+\%C3\%A7\%C3\%B6zme+becerilerine+etkisinin+in celenmesi+\&btnG $=$.

Beyer, B. K. (1987). Practical strategies for the teaching of Thinking, Boston: Allyn and Bacon.

*Can Yaşar, M. (2009). Anasınıfina devam eden altı yaş çocuklarının yaratıcı düşünme becerilerine drama eğitiminin etkisinin incelenmesi (Doktora tezi). Erişim adresi: https://tez.yok.gov.tr/UlusalTezMerkezi/tezSorguSonucYeni.jsp.

*Can Yaşar, M. ve Aral, N (2010). Yaratıcı düşünme becerilerinde okul öncesi eğitimin etkisi. Kuramsal Eğitimbilim, 3(2), 201-209.

*Can Yaşar, M. ve Aral, N (2011). Altı yaş çocuklarının yaratıcı düşünme becerilerine sosyoekonomik düzey ve anne baba öğrenim düzeyinin etkisinin incelenmesi. Kuramsal Ĕgitimbilim,4(1), 137-145.

*Çelebioğlu, B. (2009). İlköğretim birinci sınıf öğrencilerinin problem çözme stratejilerini kullanabilme düzeyleri (Yüksek lisans tezi). Erişim adresi: https://tez.yok.gov.tr/ UlusalTezMerkezi/tezSorguSonucYeni.jsp.

*Çetin, E. (2016). Okul öncesi çocukların problem çözme sürecinde teknoloji destekli şematik düzenleyicilerin kullanımına yönelik bir durum çalışması (Doktora tezi). Erişim adresi: https://tez.yok.gov.tr/UlusalTezMerkezi/tezSorguSonucYeni.jsp.

*Dağlığlu, H. E. ve Çakır, F (2007). Erken çocukluk döneminde düşünme becerilerinden planlama ve derin düşünmenin geliştirilmesi. Eğitim ve Bilim, 32(144), 28-35.

*Dereli, E. (2008). Çocuklar için sosyal beceri eğitim programının 6 yaş çocukların sosyal problem çözme becerilerine etkisi (Doktora tezi). Erişim adresi: https://scholar.google.com.tr/scholar?hl=tr\&as_sdt=0\%2C5\&q=\%C3\%87ocuklar+i\%C3\%A 7in+sosyal+beceri+e $\% \mathrm{C} 4 \% 9 \mathrm{Fitim}+$ program $\% \mathrm{C} 4 \% \mathrm{~B} 1 \mathrm{n} \% \mathrm{C} 4 \% \mathrm{~B} 1 \mathrm{n}+6+\mathrm{ya} \% \mathrm{C} 5 \% 9 \mathrm{~F}+\% \mathrm{C} 3 \%$ $\mathrm{A} 7$ ocuklar\%C4\%B1n+sosyal+problem+\%C3\%A7\%C3\%B6zme+\&btnG=.

*Dereli İman, E. (2013). Çocuklar için sosyal problem çözme ölçeği'nin 6 yaş grubu için türkiye uyarlaması ve okul öncesi davranış problemleri ile sosyal problem çözme becerileri arasındaki ilişkiler. Kuram ve Uygulamada Ĕgitim Bilimleri, 13(1), 479-498.

Emer, A. (2007). Illköğretim okullarında görev yapan öğretmenlerin düşünme becerileri ögretimine ilişkin görüşleri (Yüksek lisans tezi). Erişim adresi: https://tez.yok.gov.tr/ UlusalTezMerkezi/tezSorguSonucYeni.jsp.

*Erbay, F. ve Çağdaş, A. (2007). Annelere ilişkin bazı değişkenlerin 5-6 yaş çocuklarının yaratıcı düşüncelerine etkisi. Trakya Üniversitesi Sosyal Bilimler Dergisi, 9(1), 58-79.

*Giren, S. (2013). Sosyal problem çözme eğitiminin altı yaş çocuklarının matematik becerilerine etkisi. (Doktora tezi). Erişim adresi: https://tez.yok.gov.tr /UlusalTezMerkezi/tezSorguSonucYeni.jsp. 
Güneş, F. (2012). Öğrencilerin düşünme becerilerini geliştirme. TÜBAR, 32, 127-146.

İnci, M. A., Akpınar, Ü. ve Kandır, A. (2017). Dijital kültür ve eğitim. Gazi Üniversitesi Gazi Eğitim Fakültesi Dergisi, 37(2), 493-522.

İpekçi Çetin, E. (2002). Çok amaçlı karar verme konusunda yeni yaklaşımlar ve okul öncesi eğitime ilişkin bir uygulama, (Yüksek lisans tezi). Erişim adresi: https:// tez.yok.gov.tr/UlusalTezMerkezi/tezSorguSonucYeni.jsp.

Jones, H. (2008). Thoughts on teaching thinking: perceptions of practitioners with a shared culture of thinking skills education. The Curriculum Journal, 19(4), 309-324.

Karataş, Z. (2015). Sosyal bilimlerde nitel araştırma yöntemleri. Manevi Temelli Sosyal Hizmet Araştırmaları Dergisi, 1(1), 62-80.

Karsantık, Y. (2016). Öğretmen adaylarının düşünme becerilerine ve düşünme becerilerinin ögretimine ilişkin görüşleri (Yüksek lisans tezi). Erişim adresi: https://tez.yok.gov.tr/UlusalTezMerkezi/tezSorguSonucYeni.jsp

*Kayılı, G. (2015). Sosyal beceri eğitimi programı ile desteklenmiş montessorı yönteminin anaokulu çocuklarının duyguları anlama ve sosyal problem çözme becerilerine etkisi (Doktora tezi). Erişim adresi: https://tez.yok.gov.tr/UlusalTezMerkezi/tezSorguSonuc Yeni.jsp.

*Mutlu, E. (2010). Erken çocukluk dönemindeki çocukların (60-72 ay) düşünme düzeylerinin ve okul öncesi ögrretmenlerinin düşünme eğitimi ile ilgili tutumlarının incelenmesi (Yüksek lisans tezi). Erişim adresi: https://tez.yok.gov.tr/UlusalTezMerkezi/tezSorguSonucYeni.jsp

Nickerson, R. S. (1988). On improving thinking through instruction. Review Of Research In Education, 15, 3-57.

*Oğuz, V. (2012). Proje yaklaşımının anasınıfina devam eden çocukların problem çözme becerilerine etkisinin incelenmesi (Doktora tezi). Erişim adresi: https://tez.yok.gov.tr/ UlusalTezMerkezi/tezSorguSonucYeni.jsp.

*Özkan, H. K. (2015). Annelerin duygu sosyalleştirme davranışları ile çocukların benlik algısı ve sosyal problem çözme becerilerinin incelenmesi (Yüksek lisans tezi). Erişim adresi: https://scholar.google.com.tr/scholar?hl=tr\&as_sdt=0\%2C $5 \& \mathrm{q}=$ Annelerin+duygu+sosyalle $\% \mathrm{C} 5 \% 9$ Ftirme+davran\%C4\%B1\%C5\%9Flar\%C4\%B1+ile+\%C3\%A7ocuklar\%C4\%B1n+b enlik+alg\%C4\%B1s\%C4\%B1+ve+sosyal+problem+\%C3\%A7\%C3\%B6zme+becerilerinin+ incelenmesi+\&btnG $=$.

*Özmen, D. (2013). 5-6 yaş grubu çocukların akran ilişsilerinin sosyal problem çözme becerisi açısından incelenmesi (Yüksek lisans tezi). Erişim adresi: https://tez.yok.gov.tr/ UlusalTezMerkezi/tezSorguSonucYeni.jsp.

Scott, J. (1990). A Matter of record. Cambridge: Polity Press.

Sternberg, R. J. ve Grigorenko, E. (2004). Successful intelligence in the classroom. Theory Into Practice, 43(4), 274-280.

*Şahin, H. (2015). Psikososyal gelişim temelli eğitim programının anasınıfina devam eden çocukların duygusal zekalarına ve problem çözme becerilerine etkisi (Doktora tezi). Erişim adresi: https://tez.yok.gov.tr/UlusalTezMerkezi/tezSorguSonucYeni.jsp

*Şahintürk, Ö. (2012). Montessori yönteminin okul öncesi dönemde öğrencilerin yaratıc düşünmelerine etkisi (Yüksek lisans tezi). Erişim adresi: https://tez.yok.gov.tr/ UlusalTezMerkezi/tezSorguSonucYeni.jsp.

Şimşek, H. (2009). Eğitim tarihi araştırmalarında yöntem sorunu. Ankara Üniversitesi Eğitim Bilimleri Fakültesi Dergisi, 42(1), 33-51. 
*Tavlı, B. S. (2007). 6 yaş grubu anasınıfi öğrencilerinin problem çözme becerilerininin karşılaştırmalı olarak incelenmesi (Yüksek lisans tezi). Erişim adresi: https://tez.yok.gov.tr/UlusalTezMerkezi/tezSorguSonucYeni.jsp

Tok, E. (2008). Düşünme becerileri eğitimi programının okul öncesi öğretmen adaylarının eleştirel, yaratıcı düşünme ve problem çözme becerilerine etkisinin incelenmesi (Doktora tezi). Erişim adresi: https://tez.yok.gov.tr/UlusalTezMerkezi/tezSorguSonucYeni.jsp

Trochim,W. (2001).Bill Trochim's Center for Social Research Methods. https://www.livescience.com/21569-deduction-vs-induction.html (Erişim tarihi:12.2.2018).

Yıldırım, A. ve Şimşek, H. (2011). Sosyal bilimlerde nitel araştırma yöntemleri, Ankara: Seçkin Yayıncilik.

Yıldırım, K. (2010). Nitel Araştırmalarda Niteliği Arttırma. İlköğretim Online, 9(1), 79-92.

*Yılmaz, E. (2012). 60-72 Aylık çocukların duyguları anlama becerilerinin sosyal problem çözme becerilerine etkisinin incelenmesi (Yüksek lisans tezi). Erişim adresi: https:// tez.yok.gov.tr/UlusalTezMerkezi/tezSorguSonucYeni.jsp.

*Yılmaz, E. (2016). 48-72 aylık çocuklara yönelik sosyal problem çözme becerileri ölçeği'nin gelişstirilmesi (Doktora tezi). Erişim adresi: https://tez.yok.gov.tr/UlusalTezMerkezi/ tezSorguSonucYeni.jsp.

*Yiğitalp, N. (2014). Yönlendirilmiş beyin firtınası (scamper) tekniğine dayalı eğitimin beş yaş çocuklarının problem çözme becerilerine etkisinin incelenmesi. (Yüksek lisans tezi). Erişim adresi: https://tez.yok.gov.tr/UlusalTezMerkezi/tezSorguSonucYeni.jsp.

\section{ETIKK ve BİLIMSEL İLKELER SORUMLULUK BEYANI}

$\mathrm{Bu}$ çalışmanın tüm hazırlanma süreçlerinde etik kurallara ve bilimsel atıf gösterme ilkelerine riayet edildiğini yazar(lar) beyan eder. Aksi bir durumun tespiti halinde Afyon Kocatepe Üniversitesi Sosyal Bilimler Dergisi'nin hiçbir sorumluluğu olmayıp, tüm sorumluluk makale yazarlarına aittir. 